\title{
Genetic Relationships of Cassava Genotypes That are Susceptible or Tolerant to Cassava Brown Streak Disease in Uganda
}

\author{
Alex Abaca ${ }^{1,2}$, Robert Kawuki ${ }^{1}$, Phenihas Tukamuhabwa ${ }^{2}$, Yona Baguma ${ }^{1}$, Anthony Pariyo ${ }^{1}$, Titus Alicai ${ }^{1}$, \\ C. Christopher Omongo. ${ }^{1}$, Phillips Abidrabo ${ }^{1}$, Kasifa Katono ${ }^{1}$ \& Anton Bua ${ }^{1}$ \\ ${ }^{1}$ National Crops Resources Research Institute, Namulonge, Kampala, Uganda \\ ${ }^{2}$ Makerere University Kampala, Kampala, Uganda \\ Correspondence: Alex Abaca, National Crops Resources Research Institute, Namulonge, P.O. Box 7084, \\ Kampala, Uganda. Tel: 256-0-782-285-955. E-mail: abal-2007@hotmail.com
}

Received: June 4, 2011 Accepted: September 13, 2012 Online Published: June 15, 2013

doi:10.5539/jas.v5n7p107

URL: http://dx.doi.org/10.5539/jas.v5n7p107

\begin{abstract}
A total of 99 cassava genotypes whose field reaction to cassava brown streak disease (CBSD) was known, were assayed with 30 simple sequence repeat (SSR) markers to establish their genetic parallels. Two categories of CBSD reaction were considered: CBSD-susceptible genotypes (characterized by $>60 \%$ root and foliar CBSD incidence), and CBSD-tolerant genotypes (characterized by $<15 \%$ root and foliar CBSD incidence). DNA was extracted from leaf samples using the miniprep method and genotyped using ABI 3730 DNA sequencer. The test genotypes at 0.02 similarity coefficient, CBSD-tolerant and CBSD-susceptible genotypes clustered into 5 main sub-clusters. When data were subjected to principle component analysis (PCA) irrespective of the CBSD reaction grade, the first three principal components accounted for $68 \%$ of the total genetic variation. Despite having different number of individuals, the observed heterozygosity $\left(\mathrm{H}_{0}\right)$ for CBSD-susceptible $\left(\mathrm{H}_{\mathrm{o}}=0.58\right)$ and CBSD-tolerant $(\mathrm{Ho}=0.66)$ were comparable and provide scope for long-term CBSD breeding and/or gene tapping.
\end{abstract}

Keywords: Cassava brown streak virus, cluster analysis, foliar symptoms, simple sequence repeat marker

\section{Introduction}

Genetic diversity is essential for genetic advancement of crops and animals. For crops, by exploring the level and distribution of genetic diversity as well as the evolutionary processes shaping this diversity, plant breeders can come out with new improved varieties. Moreover, the analysis of genetic variation helps in the choice of germplasm for breeding purposes. Correct genetic analysis can lead to the identification of new combinations with maximum genetic variability, which can then be used for introgression of desirable genes into the available genetic base (Smith, 1984; Cox, Murphy, \& Rodgers, 1986; Mohammadi \& Prasanna, 2003).

Variation in allele frequency at many unlinked loci is the preferred way to assess genetic diversity and/or genetic differentiation (Nei, 1973; Wu \& Tansley, 1993). Indeed, molecular markers have been used to quantify genetic diversity in a number of crops including: sorghum (Dj'e, Heuertz, lef' ebvre, \& Vekemans, 2000); beans (Cabral et. al. (2011); Foster et al. (2010); rice (Vanniarajan, Vinod, \& Pereira, 2012); cotton (Nagaraj Basavaraddi, 2007); and finger millet (Kumari \& Pande, 2010) amongst others. For cassava genetic diversity studies have been conducted both in Latin America (Elias, Paraud \& Robert, 2000; Elias, Penet, Vindry, MacKey, Panaud \& Robert, 2001; Elias, Mühlen, Mckey, Roa, \& Tohme, 2004) and in Africa (Mkumbira et al., 2003; Fregene et al., 2003). It suffices to note that genetic diversity of cassava has been evaluated using different molecular markers: restriction fragment length polymorphisms (RFLPs) (Beeching et al., 1993); random amplified polymorphic DNA (RAPD) markers (Marmey, Beeching, Hamon, \& Charrier, 1994); simple sequence repeat markers (SSR) markers (Fregene et al., 2003), and single nucleotide polymorphism (SNPs) (Lopez et al., 2005; Kawuki, Ferguson, Labuschange, Herselman, \& Kim, 2009). In cassava, molecular markers have been used to study: (i) relationship between cassava and its wild relatives (Roa et al., 1997); (ii) intra-specific variation to enable the identification of duplicates (Beeching et al.,1993); (iii) understand genetic structure in reference to ecological adaptation (Bornierbale, Maya, Claros, \& Iglesias, 1995), and (iv) resistance and/or susceptibility to diseases (Sanchez et al., 1999; Fregene et al., 2003). In this paper we are using SSR markers to help discern the genetic relationships 
between CBSD-susceptible and CBSD-tolerant genotypes in order to efficiently design a durable CBSD breeding programme.

We have selected CBSD because it's one of the 100 most dangerous diseases in the world (Donald, 2010). CBSD is caused by cassava brown streak virus (CBSV) (Monger, Seal, Issac, \& Foster, 2001) and Uganda cassava brown streak virus (UCBSV), both of which, are prevalent in Uganda (Alicai Titus Personal Information). For over 70 years CBSD had been known to be confined to low altitude areas, especially in the coastal areas of Kenya, Tanzania and Mozambique. The presence of CBSD at high altitude areas including Uganda is just recent (Alicai et al., 2007). The disease causes characteristic above and below ground symptoms (Nichols, 1950; Hillocks \& Thresh, 2000; Hillocks \& Jennings, 2003), and as of this writing no cassava variety is resistant to it. Only a handful of tolerant varieties have been identified through field evaluations in hotspot areas (Abaca et al., 2012).

Technically, utilization of different and diverse CBSD tolerant lines would be desirable for durable CBSD breeding. Whether or not the presumed CBSD tolerate lines have a shared pedigree is unknown. It is also interesting to know the genetic relationships between the CBSD-susceptible and/or CBSD-tolerant genotypes. Thus, the overall objectives of this study were to determine the genetic relationships between CBSD-susceptible and/or CBSD-tolerant cassava genotypes using the simple sequence repeats markers.

\section{Materials and Methods}

\subsection{Plant Material and DNA Extraction}

Fresh leaf samples were collected from 100 cassava genotypes whose field reaction to CBSD was known; these materials had previously been evaluated for reaction to CBSD at Namulonge, which is a hotspot for both strains of brown streak strains (Abaca et al., 2012). Howevwer, one genotype had a lot of missing values and was omitted from the SSR analysis. The CBSD field reaction of these genotypes is presented in Table 1. DNA was extracted using the miniprep protocol as described by (Ranjana, Morag, Melaku, Dominique and Ivan (2009).

Table 1. Field reaction of the 100 test cassava genotypes to cassava brown streak disease in Uganda

\begin{tabular}{|c|c|c|c|c|c|c|c|}
\hline Genotype & $\begin{array}{l}\text { Reaction to } \\
\text { CBSD }\end{array}$ & Genotype & $\begin{array}{l}\text { Reaction to } \\
\text { CBSD }\end{array}$ & Genotype & $\begin{array}{l}\text { Reaction to } \\
\text { CBSD }\end{array}$ & Genotype & $\begin{array}{l}\text { Reaction to } \\
\text { CBSD }\end{array}$ \\
\hline Elite & & B134 & $\mathrm{S}$ & Kyembabazi & $\mathrm{S}$ & Nasiwa & $\mathrm{S}$ \\
\hline NASE 11 & $\mathrm{~S}$ & TME 05 & $\mathrm{~S}$ & Njule silverbrown & $\mathrm{S}$ & Mweru & $\mathrm{S}$ \\
\hline MH95/0402 & $\mathrm{S}$ & MM02/0258 & $\mathrm{S}$ & Kindimupale & $\mathrm{S}$ & Ntyaraboke tall & $\mathrm{S}$ \\
\hline 95/SE-00094 & S & MM01/1003 & $\mathrm{S}$ & Nyapatek & $\mathrm{S}$ & Gwalanda & S \\
\hline MM01/1457 & $\mathrm{S}$ & NASE 12 & $\mathrm{~S}$ & Kalangwa & $\mathrm{S}$ & Mpologoma & S \\
\hline Silira 15 B2 & $\mathrm{S}$ & MH04/300 & $\mathrm{S}$ & Kyemigisha & $\mathrm{S}$ & Nyapamitu & $\mathrm{S}$ \\
\hline 95/SE-0088 & $\mathrm{S}$ & MH04/0486 & $\mathrm{S}$ & Bukalasa & $\mathrm{S}$ & Bukalasa 8 & $\mathrm{~S}$ \\
\hline TZ06/130 & $\mathrm{T}$ & MH04/0479 & $\mathrm{S}$ & Siira & $\mathrm{S}$ & Rutangi & $\mathrm{S}$ \\
\hline 95/SE-00036 & $\mathrm{S}$ & MM06/400 & $\mathrm{S}$ & Masindi 2 & $\mathrm{~S}$ & Esau & S \\
\hline $\mathrm{TZ} 06 / 140$ & S & TME 204 & $\mathrm{~S}$ & Kakofira & $\mathrm{S}$ & Kalintunsi & $\mathrm{S}$ \\
\hline MM06/0532 & $\mathrm{S}$ & $/ 0427$ & $\mathrm{~S}$ & Kalisa & $\mathrm{S}$ & Birungi & $\mathrm{S}$ \\
\hline MM06/529 & $\mathrm{S}$ & 349 KAK & $\mathrm{S}$ & Tamale & $\mathrm{S}$ & Ssesubiri & S \\
\hline I92/00067 & $\mathrm{S}$ & MM96/0686 & $\mathrm{T}$ & Kabiriti & $\mathrm{S}$ & Serubola & $\mathrm{S}$ \\
\hline MM97/2358 & $\mathrm{S}$ & NASE 1 & $\mathrm{~T}$ & Abigaba & $\mathrm{S}$ & Rusidi & $\mathrm{S}$ \\
\hline NASE 4 & $\mathrm{~S}$ & CR 20A - 1 & $\mathrm{~T}$ & Kirimupale & $\mathrm{S}$ & Kasule & $\mathrm{S}$ \\
\hline MH04/1636 & $\mathrm{S}$ & $\mathrm{MH} 04 / 0042 \mathrm{~A}$ & $\mathrm{~S}$ & Alado alado & $\mathrm{S}$ & Kabwa & $\mathrm{S}$ \\
\hline TME 14 & $\mathrm{~S}$ & 266 BAM & $\mathrm{S}$ & Tim Tim & $\mathrm{S}$ & Luhujo white & $\mathrm{S}$ \\
\hline $\mathrm{I} 92 / 00057$ & S & MH97/2961 & $\mathrm{S}$ & Ntangali & $\mathrm{S}$ & Bamunanika & S \\
\hline $96 / 1630$ & $\mathrm{~S}$ & Local & & Matooke & $\mathrm{S}$ & Kibao & $\mathrm{S}$ \\
\hline MH04/0016 & $\mathrm{S}$ & Nyarunega & $\mathrm{S}$ & Mukuma & $\mathrm{S}$ & Lukiru & $\mathrm{S}$ \\
\hline MH04/2018 & S & MM96/0876 & $\mathrm{S}$ & Masindi 3 & $\mathrm{~S}$ & Kamuhanda & $\mathrm{S}$ \\
\hline MM02/0169 & $\mathrm{S}$ & Njule white & $\mathrm{S}$ & Kabagambe & $\mathrm{S}$ & Kiberu & $\mathrm{S}$ \\
\hline MM02/1970 & $\mathrm{S}$ & Njule zigzag & $\mathrm{S}$ & Kisembo & $\mathrm{S}$ & Bao & $\mathrm{S}$ \\
\hline NASE 3 & S & Nyamatia & $\mathrm{S}$ & Masindi 1 & $\mathrm{~S}$ & Rwamutere & S \\
\hline MM98/3055 & $\mathrm{S}$ & Kamia & $\mathrm{S}$ & Sentongo & $\mathrm{S}$ & & \\
\hline MM96/4271 & $\mathrm{T}$ & Njule red & $\mathrm{S}$ & Lugujo brown & $\mathrm{S}$ & & \\
\hline
\end{tabular}

Susceptible genotypes characterized by $>60 \%$ root and foliar CBSD incidence; tolerant genotypes characterized by $<15 \%$ root and foliar CBSD incidence. 


\subsection{DNA Genotyping}

Polymerase chain reaction (PCR) amplifications with 30 SSR primers (Table 2) were performed in $10 \mu 1$ reactions that contained $10 \mathrm{ng}$ of DNA, 1 mole of each primer, 1x Taq polymerase buffer, $2 \mathrm{mM} \mathrm{Mgcl}_{2}, 0.2 \mathrm{mM}$ deoxynucleotide triphosphates (dNTPs) and $0.375 \mathrm{U} \mathrm{Taq}$ polymerase (New England Biolabs Inc.). The PCR profile was $95^{\circ} \mathrm{C}$ for $2 \mathrm{~min}$, followed by 30 cycles of $95^{\circ} \mathrm{C}$ for $30 \mathrm{sec}, 45-55^{\circ} \mathrm{C}$ for $1 \mathrm{~min}$ and $72^{\circ} \mathrm{C}$ for $1 \mathrm{~min}$ and a final extension at $72^{\circ} \mathrm{C}$ for $30 \mathrm{~min}$. Based on previous studies, these $30 \mathrm{SSR}$ markers were chosen because of their diallelic nature, reproducibility and distribution across the genome (Moyib, Odunola, \& Dixon, 2007; Raghu et al., 2007). Aliquots of $1 \mu \mathrm{l}$ of the PCR products were added to $9 \mu \mathrm{l}$ of the master-mix that contained HiDi formamide and GeneScan-500 LIZ size standard ( $1 \mathrm{ml}$ of HiDi $+12 \mu 1$ of 500-LIZ). Amplicons were denatured $\left(95^{\circ} \mathrm{C}\right.$ for $3 \mathrm{~min}$ ) and subjected to capillary electrophoresis using the ABI 3730 DNA sequencer (Applied Biosystems) and allele calls made using the GeneMapper ver. 3.7 software (Applied Biosystems). All genotyping work was done at the Biosciences eastern and central Africa (BecA) hub in Nairobi, Kenya.

Table 2. SSR locus, genetic map location, primer sequences, and annealing temperature of markers used for genotyping

\begin{tabular}{|c|c|c|c|c|c|}
\hline $\begin{array}{l}\text { SSR } \\
\text { locus }\end{array}$ & $\begin{array}{l}\text { Genetic } \\
\text { Map } \\
\text { Location } \\
\end{array}$ & Left primer (Reverse) & Right primer (Forward) & $\begin{array}{l}\text { Product } \\
\text { Size (bp) }\end{array}$ & $\begin{array}{l}\mathrm{T} \\
\left({ }^{\circ} \mathrm{C}\right)\end{array}$ \\
\hline SSRY9 & $\mathrm{D}$ & ACAATTCATCATGAGTCATCAACT & CCGTTATTGTTCCTGGTCCT & 278 & 55 \\
\hline SSRY12 & I & AACTGTCAAACCATTCTACTTGC & GCCAGCAAGGTTTGCTACAT & 266 & 55 \\
\hline SSRY19 & K & TGTAAGGCATTCCAAGAATTATCA & TCTCCTGTGAAAAGTGCATGA & 214 & 55 \\
\hline SSRY20 & $\mathrm{R}$ & CATTGGACTTCCTACAAATATGAAT & TGATGGAAAGTGGTTATGTCCTT & 143 & 55 \\
\hline SSRY21 & $\mathrm{N}$ & CCTGCCACAATATTGAAATGG & CAACAATTGGACTAAGCAGCA & 192 & 55 \\
\hline SSRY34 & $\mathrm{F}$ & TTCCAGACCTGTTCCACCAT & ATTGCAGGGATTATTGCTCG & 279 & 55 \\
\hline SSRY38 & G & GGCTGTTCGTGATCCTTATTAAC & GTAGTTGAGAAAACTTTGCATGAG & 122 & 55 \\
\hline SSRY51 & $\mathrm{E}$ & AGGTTGGATGCTTGAAGGAA & GGATGCAGGAGTGCTCAACT & 298 & 55 \\
\hline SSRY52 & I & GCCAGCAAGGTTTGCTACAT & AACTGTCAAACCATTCTACTTGC & 266 & 55 \\
\hline SSRY59 & M & GCAATGCAGTGAACCATCTTT & CGTTTGTCCTTTCTGATGTTC & 158 & 55 \\
\hline SSRY63 & nd & TCAGAATCATCTACCTTGGCA & AAGACAATCATTTTGTGCTCCA & 290 & 55 \\
\hline SSRY64 & $\mathrm{H}$ & CGACAAGTCGTATATGTAGTATTCACG & GCAGAGGTGGCTAACGAGAC & 194 & 55 \\
\hline SSRY69 & $\mathrm{E}$ & CGATCTCAGTCGATACCCAAG & CACTCCGTTGCAGGCATTA & 239 & 55 \\
\hline SSRY82 & $\mathrm{O}$ & TGTGACAATTTTCAGATAGCTTCA & CACCATCGGCATTAAACTTTG & 211 & 55 \\
\hline SSRY100 & $\mathrm{P}$ & ATCCTTGCCTGACATTTTGC & TTCGCAGAGTCCAATTGTTG & 210 & 55 \\
\hline SSRY102 & $\mathrm{F}$ & TTGGCTGCTTTCACTAATGC & TTGAACACGTTGAACAACCA & 179 & 55 \\
\hline SSRY103 & B & TGAGAAGGAAACTGCTTGCAC & CAGCAAGACCATCACCAGTTT & 272 & 55 \\
\hline SSRY105 & G & CAAACATCTGCACTTTTGGC & TCGAGTGGCTTCTGGTCTTC & 225 & 55 \\
\hline SSRY106 & B & GGAAACTGCTTGCACAAAGA & CAGCAAGACCATCACCAGTTT & 270 & 55 \\
\hline SSRY108 & $\mathrm{D}$ & ACGCTATGATGTCCAAAGGC & CATGCCACATAGTTCGTGCT & 203 & 55 \\
\hline SSRY110 & $\mathrm{X}$ & TTGAGTGGTGAATGCGAAAG & AGTGCCACCTTGAAAGAGCA & 247 & 55 \\
\hline SSRY135 & G & CCAGAAACTGAAATGCATCG & AACATGTGCGACAGTGATTG & 253 & 45 \\
\hline SSRY161 & $\mathrm{E}$ & AAGGAACACCTCTCCTAGAATCA & CCAGCTGTATGTTGAGTGAGC & 220 & 55 \\
\hline SSRY164 & $\mathrm{H}$ & TCAAACAAGAATTAGCAGAACTGG & TGAGATTTCGTAATATTCATTTCACTT & 187 & 45 \\
\hline SSRY171 & $\mathrm{C}$ & ACTGTGCCAAAATAGCCAAATAGT & TCATGAGTGTGGGATGTTTTTATG & 291 & 55 \\
\hline SSRY177 & $\mathrm{U}$ & ACCACAAACATAGGCACGAG & CACCCAATTCACCAATTACCA & 268 & 45 \\
\hline SSRY179 & nd & CAGGCTCAGGTGAAGTAAAGG & GCGAAAGTAAGTCTACAACTTTTCTAA & 226 & 55 \\
\hline SSRY180 & E & CCTTGGCAGAGATGAATTAGAG & GGGGCATTCTACATGATCAATAA & 163 & 55 \\
\hline SSRY181 & K & GGTAGATCTGGATCGAGGAGG & CAATCGAAACCGACGATACA & 199 & 55 \\
\hline SSRY182 & Q & GGAATTCTTTGCTTATGATGCC & TTCCTTTACAATTCTGGACGC & 253 & 55 \\
\hline
\end{tabular}

$\mathrm{nd}=$ Genetic location not known, and $\mathrm{T}=$ temperature in degree Celsius.

\subsection{Data Analysis}

The generated diploid genetic data was used to generate allelic frequency and dissimilarity matrices using GeneAlex software, ver. 6.4 (Peakall \& Smouse, 2006). Further, cluster analyses were performed to measure the degree of relatedness between accessions in the DARwin5 software, ver. 5.0.158 (Perrier \& Jacquemound, 2006) based on the UPGMA method. 


\section{Results}

\subsection{Genetic Relationships between CBSD-Tolerant and CBSD-Susceptible Cassava Genotypes}

A total of 30 SSR loci were analyzed in 99 cassava genotypes classified as either CBSD-susceptible (94 genotypes) or CBSD-tolerant (five genotypes). As of this writing we only have five cassava genotypes that can be classified as tolerant i.e., with CBSD root and foliar incidence $\leq 15 \%$. Most of the cassava varieties available in the Ugandan germplasm are highly susceptible to CBSD. The dendrogram of genetic similarity of the test genotypes with the coefficient of genetic similarity ranging from 0 to 0.1 , is presented in Figure 1. Two main grouping were apparent, with only one CBSD-tolerant genotype (NASE 1) being assigned to one cluster and the other four CBSD-tolerant genotypes (CR 20A -1, MM96/4271, MM96/0686 and TZ 06/130) being assigned to the second cluster. However, at 0.02 similarity coefficient, the genotypes clustered into 5 main sub-clusters. The first sub-cluster consisted of 40 genotypes including the four CBSD-tolerant genotypes (Figure 1). The second sub-cluster consisted of only five CBSD-susceptible genotypes. The third sub-cluster consisted of 51 genotypes of which only NASE 1 was CBSD-tolerant. The fourth and fifth sub-clusters consisted respectively of two and one CBSD- susceptible genotypes.

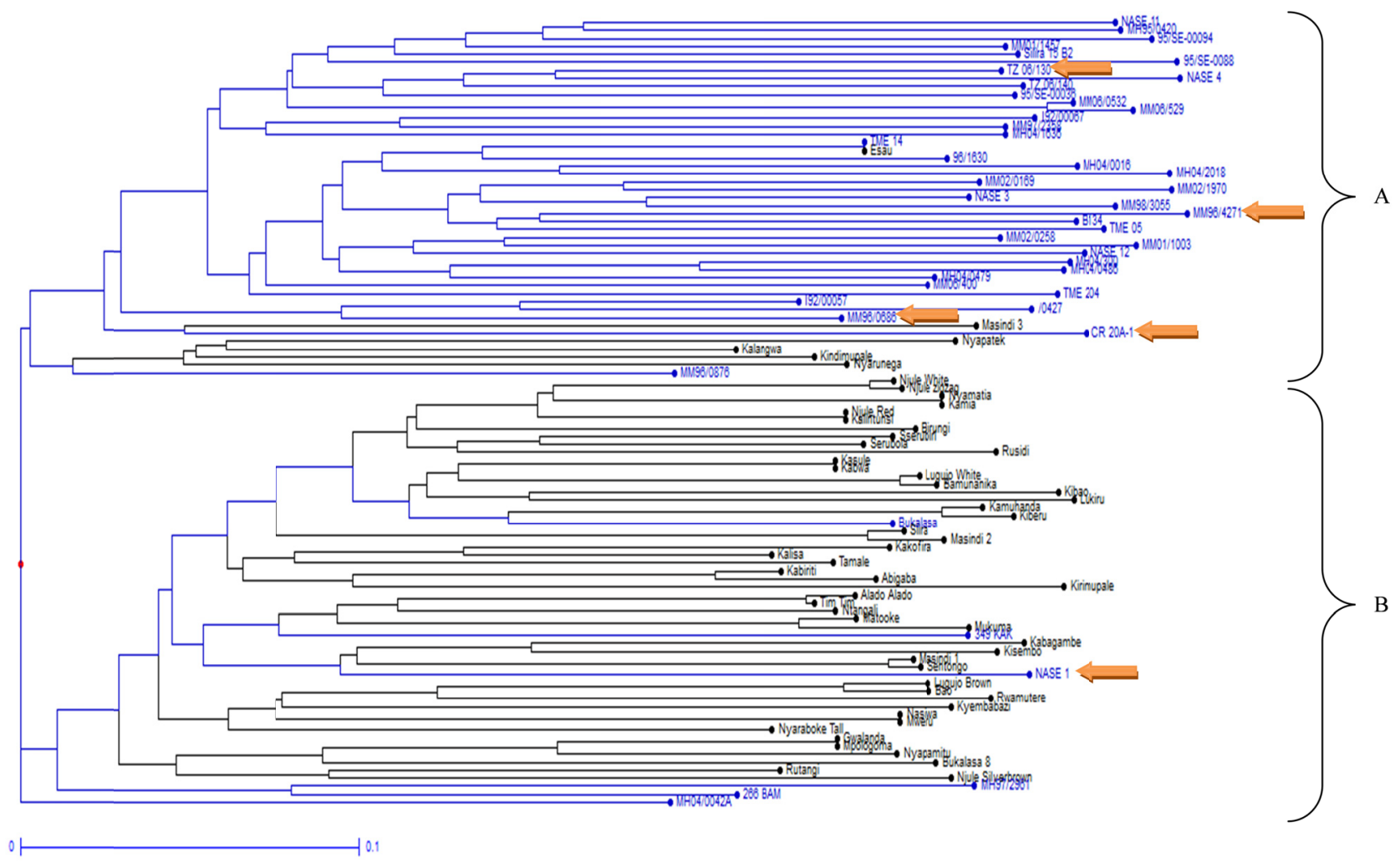

Figure 1. UPGMA dendrogram of 99 cassava genotypes based on the dissimilarity matrix calculated from the SSR markers. The arrow show the position of the CBSD-tolerant genotypes (NASE 1, CR20A-1, MM96/0686, MM96/4271 and TZ06/130) 


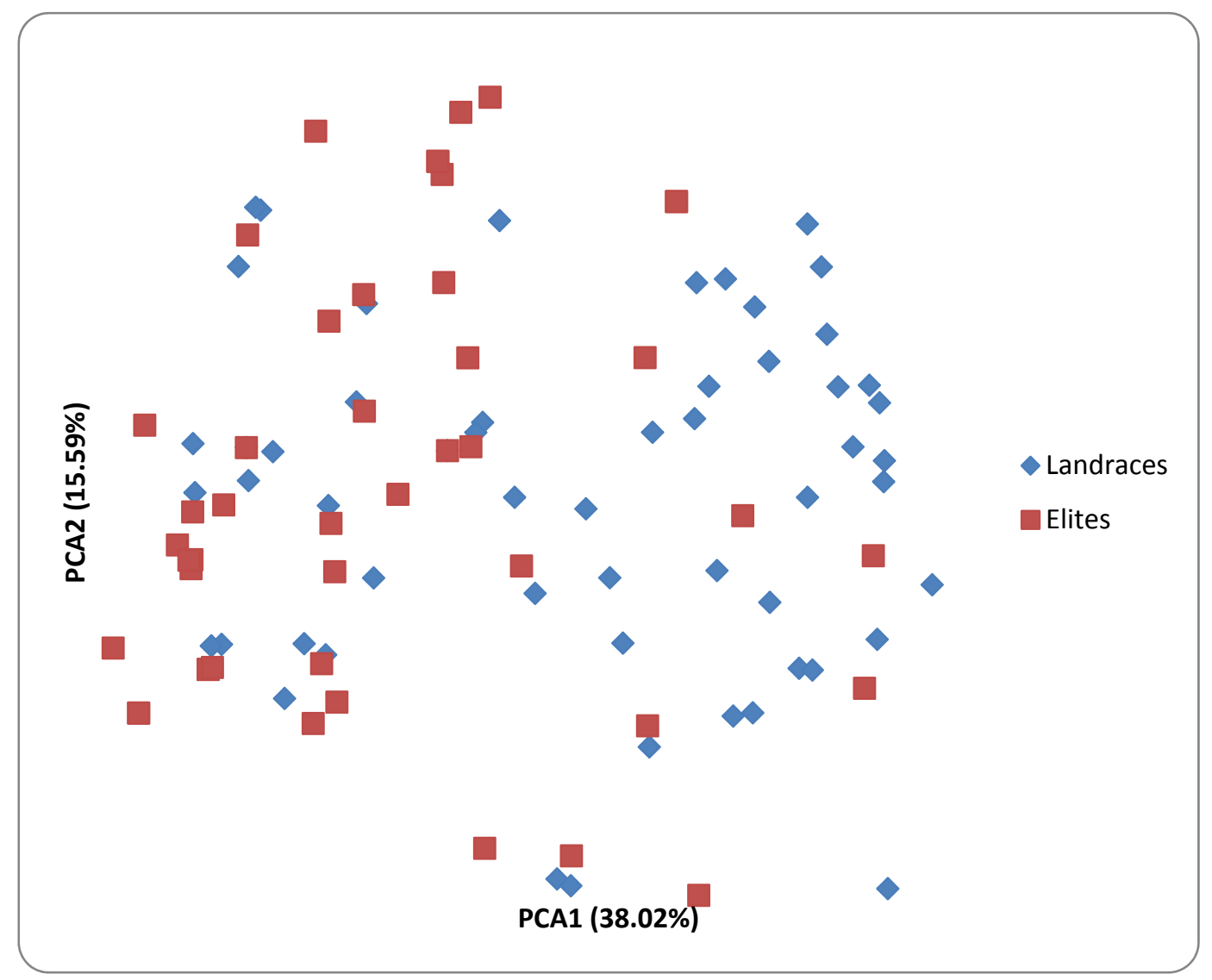

Figure 2. Principle component analysis of 99 cassava genotypes analyzed using 30 SSR markers

\subsection{Genetic Diversity of Elite and Local Cassava Genotypes}

When the genotypic data were re-analyzed with cassava classified as either local (cassava commonly grown by farmers and not resulting from a formal breeding process) or elite (cassava resulting from a formal breeding process), the results showed that local genotypes had relatively more allelic diversity than their elite counterparts (Table 3). Observed heterozygosity $\left(\mathrm{H}_{\mathrm{o}}\right)$ was also high in all the two classification with the averages of $0.61 \pm 0.04$ and $0.62 \pm 0.004$ for the local and elite genotypes respectively (Table 3). Similarly, expected heterozygosity $\left(\mathrm{H}_{\mathrm{e}}\right)$ was high within the local genotypes than the elite (Table 3). Analysis of molecular variance (AMOVA) revealed that $98 \%$ of the genetic variation was distributed among individual genotypes and not groups that is, between elite and local genotypes. Results from principle component analysis showed similar groupings with the majority of the elite genotypes somewhat clustering separately from the local genotypes (Figure 2). The first three principal components accounted for $38.02 \%, 15.59 \%$ and $14.84 \%$ of the total genetic variation, respectively.

Table 3. Number of alleles per SSR locus and genetic diversity parameters for local and elite cassava genotypes

\begin{tabular}{|c|c|c|c|c|c|c|}
\hline Populations & $\begin{array}{l}\text { Sample size } \\
\text { (n) }\end{array}$ & $\mathrm{Na}$ & $\mathrm{Ne}$ & $\mathrm{H}_{\mathrm{o}}$ & $\mathrm{H}_{\mathrm{e}}$ & $\mathrm{UHe}$ \\
\hline Local & 54 & $5.1 \pm 0.32$ & 3.13 & $0.61 \pm 0.04$ & $0.61 \pm 0.03$ & 0.61 \\
\hline Elite & 45 & $4.6 \pm 0.29$ & 2.89 & $0.62 \pm 0.04$ & $0.58 \pm 0.03$ & 0.59 \\
\hline Mean & 49.5 & $4.9 \pm 0.31$ & 3.01 & $0.62 \pm 0.04$ & $0.6 \pm 0.03$ & 0.601 \\
\hline
\end{tabular}

$\mathrm{Na}=$ Average number of different alleles, $\mathrm{Ne}=$ Average number of effective alleles, $\mathrm{Ho}=$ average observed heterozygosity, $\mathrm{He}=$ Average expected heterozygosity and $\mathrm{UHe}=$ Average unbiased expected heterozygosity . 


\section{Discussion}

The major objective of this study was to establish whether or not the CBSD-Tolerant and CBSD-susceptible genotypes are genetically similar. The CBSD-tolerant genotypes (NASE 1, CR 20A -1, MM96/4271, MM96/0686 and TZ 06/130) were placed in two separate clusters; one cluster had only one genotype (NASE 1) and the other cluster had the remaining four genotypes. NASE 1 also referred to as TMS 60142 is one of the Tropical Manihot Selections that were derived from clone 58308 (a third backcross) at Amani, Tanzania, where the pioneer CBSD breeding efforts were undertaken. This genotype was officially released in Uganda in the early 1990s owing to its resistance to CMD, the key viral constraint then. On the other hand, both MM96/4271 and MM96/0686 are genotypes from the International Institute of Tropical Agriculture (IITA) breeding programme; TZ06/130 was selected from open pollinated seeds sourced from CBSD-tolerant genotypes in Tanzania; and CR20A-1 is a Latin American genotype sourced from International Centre for Tropical Agriculture (CIAT). Basing on these results, it's likely that we are dealing with different sources of CBSD tolerance, which appears to be consistent with the aforementioned historical pedigree information. It is therefore envisaged that combining genotypes from the different clusters and/or sub-clusters as parents in the breeding programme would result into diversifying and/or increasing the dosage effects required for durable CBSD resistance breeding.

The implications of this study are of direct relevance towards the management and control of the spread of CBSD, and in breeding for resistance. Several surveys conducted in East and Central Africa (Legg \& Pheneas, 2007) have shown that there are severe forms of the CBSD due to cassava brown streak virus (CBSV) and Uganda cassava brown streak virus (UCBSV), and that the disease has spread to neighbouring countries such as Democratic Republic of Congo, Rwanda, Burundi amongst others. In managing the spread of the disease, cultivating tolerant genotypes has been demonstrated as the most effective means (ASERECA, 2009). In the absence of resistant varieties, it's these tolerant varieties that can be multiplied and thereafter distributed to farmers. However, because they are not immune to CBSVs, their usefulness will be short-lived as a result of accumulation of virus with each cycle of propagation. Nonetheless, these tolerant genotypes should be able to provide descent yields even with the fifth cycle of propagation after which, virus elimination should be done using tissue culture techniques.

In parallel, the identified tolerant genotypes can be utilized to initiate a breeding scheme that pyramids CBSD tolerance alleles. Inter-mating CBSD tolerant cassava genotypes which have other desirable agronomic and/or consumer quality traits, from the different sub-clusters would ensure the diversification of tolerance to the disease while creating new genotypes. Preliminary information on the genetics of inheritance for CBSD indicate that both additive and non-additive gene effects are important (Munga, 2008) and thus justifying the need for recurrent selection for CBSD breeding. With this in mind, the tolerate lines can be crossed in different combinations to generate progeny for further evaluation and hybridization. In addition, by combining different genes that relate to different sources of resistance, epistatic interaction may be identified such that higher levels of resistance can be developed.

High levels of heterozygosity were observed in the cassava genotypes, with an average of 0.611 for both local and elite cassava genotypes. These high levels of heterozygosity can be attributed to the out-crossing nature of cassava. This is similar to the explanation of Karuri, Ateka, Amata, Nyende and Muigai (1998) that self incompatibility in the flowers of sweet potatoes results in allogamy, thus, increasing genetic heterozygosity. Furthermore, despite some differences in allelic diversity and the observed clustering, most variation was detected within individuals, which accounted for $98 \%$ of the total genetic variation, a finding which further confirms the heterozygous nature of cassava.

This is the first methodical analysis of genetic relationships between CBSD-susceptible and CBSD-tolerant cassava genotypes in Uganda. Our findings indicate that the current sources of CBSD tolerance are distinct, which is desirable when dealing with viral pathogens that are highly variable and/or have potential to mutate. The tolerant genotypes can either be hybridized amongst themselves to concentrate favorable alleles and/or selfed to fix the desirable alleles.

\section{Acknowledgement}

The authors thank the Millennium Science Initiative (MSI) that provided financial support through the Uganda National Council for Science and technology (UNCST). We are grateful to the technicians of the National Cassava programme for their support towards data collection and trial management. 


\section{References}

Abaca, A., Kawuki, R., Tukamuhabwa, P., Baguma, Y., Pariyo, A., Alicai, T., ... Bua, A. (2012). Evaluation of Local and Elite Cassava Genotypes for Resistance to Cassava Brown Streak Disease (CBSD) in Uganda. Journal of Agronomy, 11(3), 65-72. http://dx.doi.org/10.3923/ja.2012.65.72

Alicai, T., Omongo, C. A., Maruthi, M. N., Hillocks, R. J., Baguma, Y., Kawuki, R., ... Colvin, J. (2007). Re-emergence of cassava brown streak disease in Uganda. Plant Disease, 91, 24-29. http://dx.doi.org/10.1094/PD-91-0024

ASERECA. (2009). Communication and training resource kit for the awareness campaign on cassava brown streak disease. Staple Crops Programme, Plot 5 Mpigi Road, P.O Box 765, Entebbe - Uganda.

Beeching, J. R., Marmey, P, Gavalda, M. C., Noirot, M., Hayson, H. R., Hughes, M. A., \& Charrier, A. (1993). An assessment of genetic diversity within a collection of cassava (Manihot esculenta, Crantz) germplasm using molecular markers. Annals of Botany, 72(6), 515-571. http://dx.doi.org/10.1006/anbo.1993.1139

Bonierbale, M. W., Maya, M. M., Claros, J. L., \& Iglesias, C. (1995). Application of molecular markers to describing the genetic structure of cassava gene pools. In Proceedings of the Second International Scientific Meeting of the Cassava Biotechnology Network, Bogor, Indonesia, 22-26 August 1994, Volume I. CIAT Working document No. 150. CIAT, Cali, Colombia (pp 106-112).

Cabral, P. D. S., Soares, T. C. B., Lima, A. B. P., de Miranda, F. D., Souza, F. B., \& Gonçalves, L. S. A. (2011). Genetic diversity in local and commercial dry bean (Phaseolus vulgaris) accessions based on microsatellite markers. Genetics and Molecular Research, 10(1), 140-149. http://dx.doi.org/10.4238/vol10-1gmr993

Cox, T., Murphy, J., \& Rodgers, D. (1986). Changes in genetic diversity in the red winter wheat regions of the United States. Proceedings of the National Academy of Science (USA), 83, 5583-5586. http://dx.doi.org/10.1073/pnas.83.15.5583

Dj’e, Y., Heuertz, M., Lef' ebyre, C., \& Vekemans, X. (2000). Assessment of genetic diversity within and among germplasm accessions in cultivated sorghum using microsatellite markers. Theoretical and Applied Genetics, 100, 918-925. http://dx.doi.org/10.1007/s001220051371

Donald, G. M. J. (2010). Virus Ravages Cassava Plants in Africa. The New York Times, Published on May 31, 2010. Retrieved 11th October, 2011, from http://www.nytimes.com/2010/06/01/science/01 cassava.html

Elias, M., Mühlen, G. S, McKey, D., Roa, A. C., Tohme, J. (2004). Genetic diversity of traditional South American landraces of cassava (Manihot esculenta Crantz): an analysis using microsatellites. Economic Botany, 58, 242-256. http://dx.doi.org/10.1663/0013-0001(2004)058[0242:GDOTSA]2.0.CO;2

Elias, M., Paraud, O., Robert, T. (2000). Assessment of genetic variability in a traditional cassava (Manihot esculenta Crantz) farming system using AFLP markers. Heredity, 85(3), $219-230$. http://dx.doi.org/10.1046/j.1365-2540.2000.00749.x

Elias, M., Penet, L., Vindry, P., MacKey, D., Panaud, O., \& Robert, T. (2001). Unmanaged sexual reproduction and the dynamics of genetic diversity of a vegetatively propagated crop plant, cassava (Manihot esculenta Crantz), in a traditional farming system. Molecular Ecolology, 10, 895-907. http://dx.doi.org/10.1046/j.0962-1083.2001.01331.x

Schork, N. J., Fallin, D., \& Lanchbury, J. S. (2000). Single nucleotide polymorphisms and the future of genetic epidemiology. Clinical genetics, 58(4), 250-264. http://dx.doi.org/10.1186/1471-2229-10-13

Fregene, M., Suarez, M., Mkumbira, J., Kulembeka, H., Ndedya. E., Kulaya, A., ... Kresovich, S. (2003). Simple sequence repeat marker diversity in cassava landraces: genetic diversity and differentiation in an asexually propagated crop. Theoretical and Applied Genetics, 107, 1083-1093. http://dx.doi.org/10.1007/s00122-003-1348-3

Hillocks, R. J., \& Thresh, M. J. (2000). Cassava mosaic and cassava brown streak virus- diseases in Africa. Roots, 7, 1-12. http://dx.doi.org/10.1080/0967087031000101061

Hillocks, R. J., \& Jennings, D. L. (2003). Cassava brown streak disease: a review of present knowledge and research needs. International Journal of Pest Management, 49, 225-234.

Karuri, H. W., Ateka, E. M., Amata, R., Nyende, A. B., \& Muigai, A. W. T. (1998). Characterization of Kenyan sweet potato genotypes for SPVD resistance and high dry matter content using simple sequence repeat markers. African Journal of Biotechnology, 8(10), 2169-2175. 
Kawuki, R. S., Ferguson, M., Labuschagne, M., Herselman, L., \& Kim, D. (2009). Identification, characterisation and application of single nucleotide polymorphisms for diversity assessment in cassava (Manihot esculenta Crantz). Molecular Breeding, 23, 669-684. http://dx.doi.org/10.1007/s11032-009-9264-0

Kumari, K., \& Pande, A. (2010). Study of genetic diversity in finger millet (Eleusine coracana L. Gaertn) using RAPD markers. African Journal of Biotechnology, 9(29), 4542-4549. Retrieved from http://www.academicjournals.org/AJB

Legg, J. P., \& Pheneas, N. (2007). New spread of cassava brown streak virus disease and its implications for the movement of Germplasm in the East and Central African Region. International Journal of Pest Management, $53,179-182$.

Lopez, C., Piegu, B., Cooke, R., Delsen, M., Tohme, J., \& Verdier, V. (2005). Using cDNA and genomic sequences as tools to develop SNP strategies in cassava (Manihot esculenta Crantz). Theoretical and Applied Genetic, 110, 425-431. http://dx.doi.org/10.1007/s00122-004-1833-3

Marmey, P, Beeching, J. R., Hamon, S., \& Charrier, A. (1994). Evaluation of cassava (Manihot esculenta Crantz) germplasm collection using RAPD markers. Euphytica, 14, 203-209. http://dx.doi.org/10.1007/BF00040402

Mkumbira, J., Chiwona-Karltun, L., Lagercrantz, U., Mahungu, N. M., Saka, J., Mhone, A., ... Rosling, H. (2003). Classification of cassava into 'bitter' and 'cool' in Malawi: from farmers' perception to characterisation by molecular markers. Euphytica, 132, 7-22. http://dx.doi.org/10.1023/A:1024619327587

Mohammadi, S., \& Prasanna, B. (2003). Review \& interpretation. Analysis of genetic diversity in crop plants. Crop Science, 43, 1235-1248. http://dx.doi.org/10.2135/cropsci2003.1235

Monger, W. A., Seal, S., Issac A. M., \& Foster, G. D., (2001a). Molecular characterization of the cassava brown streak virus coat protein. Plant pathology, 50, 527-534. http://dx.doi.org/10.1046/j.1365-3059.2001.00589.x

Moyib O. K., Odunola O. A., Dixon A. G. O. (2007). SSR markers reveal genetic variation between improved cassava cultivars and landraces within a collection of Nigerian cassava germplasm. African Journal of Biotechnology, 6(23), 2666-2674.

Munga Theresia Luvuno. (2008). Breeding for Cassava Brown Streak Resistance in Coastal Kenya. PhD thesis, Faculty of Science and Agriculture, University of KwaZulu-Natal, Republic of South Africa.

Nagaraj, B. (2007). Genetic diversity studies in Gossypium hirsutum L.Cotton, for Yield contributing characters, Fibre traits and in Vitro Regeneration. MSc Thesis. University of Agricultural Sciences, Dharwad.

Nei, M. (1973). Analysis of gene diversity in subdivided populations. Proceedings of the National Academy of Science, 70, 3321-3323. http://dx.doi.org/10.1073/pnas.70.12.3321

Nichols, R. F. W. (1950). The brown streak disease of cassava: distribution climatic effects and diagnostic symptom. East African Agriculture, 15, 154-160.

Peakall, R., \& Smouse, P. E. (2006). GENALEX 6: Genetic analysis in Excel. Population genetic software for $\begin{array}{lllll}\text { teaching and } & \text { Molecular Ecology }\end{array}$ http://dx.doi.org/10.1111/j.1471-8286.2005.01155.x

Perrier, X., \& Jacquemound-Collet, J. P. (2006). DARwin Software. Retrieved May 15th, 2011, from http://darwin.cirad.fr/darwin

Raghu, D., Senthil, N., Saraswathi, T., Raveendran, M., Gnanam, R., Venkatachalam, R., ... Mohan, C. (2007). Morphological and simple sequence repeats (SSR) based fingerprinting of South Indian cassava germplasm. International Journal of Integrative Biology, 1(2), 141-148.

Ranjana, B., Morag, F., Melaku, G., Dominique, D., \& Ivan, I. (2009). Field collection, preservation and large scale DNA extraction procedures for cassava (Manihot esculenta Crantz). African Journal of Biotechnology, $8(15), 3424-3430$.

Roa, A., Maya, M., Duque, M., Tohme, J., Allem, A., \& Bonierbale, M. (1997). AFLP analysis of the relationships among cassava and other Manihot species. Theoretical and Applied Genetics, 95, 741-750. http://dx.doi.org/10.1007/s001220050620

Sanchez, G., Restrepo, S., Duque, M., Fregene, M., Bonierbale, M. W., \& Verdier, V. (1999). AFLP assessment of genetic variability in cassava accessions (Manihot esculenta Crantz) resistant and susceptible to the cassava bacterial blight (CBB). Genome, 42, 163-172. http://dx.doi.org/10.1139/g98-124 
Smith, J. (1984). Genetic variability within U.S. hybrid maize: multivariate analysis of isozyme data. Crop Science, 24, 1041-1046. http://dx.doi.org/10.2135/cropsci1984.0011183X002400060009x

Vanniarajan, C., Vinod, K. K., \& Pereira, A., (2012). Molecular evaluation of genetic diversity and association studies in rice (Oryza sativa L.). Journal of Genetics, 91, 9-19. http://dx.doi.org/10.1007/s12041-012-0146-6

Wu, K. S., \& Tanksley, S. D. (1993). Abundance, polymorphism and genetic mapping of microsatellites in rice. Molecular Genetics and Genomics, 241, 225-235.

\section{Copyrights}

Copyright for this article is retained by the author(s), with first publication rights granted to the journal.

This is an open-access article distributed under the terms and conditions of the Creative Commons Attribution license (http://creativecommons.org/licenses/by/3.0/). 